\title{
Multilevel Analysis on the Determinants of Overweight among Children Under Five in Kediri, East Java
}

\author{
Alfadefi Khalifatunisak), Harsono Salimo²), Yulia Lanti Retno Dewi3) \\ 1)Masters Program in Public Health, Universitas Sebelas Maret \\ 2)Faculty of Medicine, Universitas Sebelas Maret
}

\begin{abstract}
Background: Child overweight and obesity are an important public health issue worldwide. Overweight and obese children are likely to stay obese into adulthood and more likely to develop non-communicable diseases like diabetes and cardiovascular diseases. This study aimed to determine factors associated with overweight among children under five in Kediri, East Java, using a multilevel analysis model.

Subjects and Method: This was a case control study conducted at 25 posyandus (integrated family health posts) in Kediri, East Java, from April to May 2018. A sample of 200 children under five was selected by fixed disease sampling. Posyandu was selected by stratified random sampling. Children were located at level 1 and posyandu at level 2 in the multilevel analysis model. The dependent variable was overweight. The independent variables were maternal body mass index (BMI), exclusive breastfeeding, calorie intake, feeding pattern, and nutritional status monitoring. Overweight status was measured by weight for height z-score. The data were collected by questionnaire and analyzed by a multilevel logistic regression model run in Stata 13.

Results: Maternal BMI $\geq 25(b=0.72 ; 95 \% \mathrm{CI}=-0.98$ to $1.54 ; \mathrm{p}=0.085)$ and calorie intake exceeding the recommended allowance $(b=1.45 ; 95 \% \mathrm{CI}=0.59$ to $2.31 ; \mathrm{p}=0.001)$ increased the risk of overweight in children under five. Good feeding pattern $(b=-1.11 ; 95 \% \mathrm{CI}=-2.15$ to -0.08 ; $\mathrm{p}=0.034)$, exclusive breastfeeding $(\mathrm{b}=-0.97 ; 95 \% \mathrm{CI}=-1.98$ to $0.02 ; \mathrm{p}=0.057)$, and regular nutritional status monitoring $(b=-4.34 ; 95 \% \mathrm{CI}=-6.42$ to $-2.21 ; \mathrm{p}<0.001)$ decreased the risk of overweight. Posyandu showed negligible contextual effect on the incidence of child overweight with ICC $=0.98 \%$.

Conclusion: Maternal BMI $\geq 25$ and calorie intake exceeding the recommended allowance increase the risk of overweight in children under five. Good feeding pattern, exclusive breastfeeding, and regular nutritional status monitoring decrease the risk of overweight in children under five. Posyandu has a negligible contextual effect on child overweight.
\end{abstract}

Keywords: overweight, children under five, exclusive breastfeeding, maternal body mass index, multilevel analysis

\section{Correspondence:}

Alfadefi Khaliatunnisak. Masters Program in Public Health, Universitas Sebelas Maret, Jl. Ir. Sutami 36 A, Surakarta 57126, Central Java. Email: emailealfadefig99@gmail.com.

\section{BACKGROUND}

Obesity is still a problem that is in the spotlight of the world. WHO has declared that obesity is a global endemic problem. An International Obesity Institute in London states that 1.7 billion people on Earth are overweight (Setiyaningsih et al., 2015). It is estimated that there are 3.4 million cases of child deaths in the world in
2010 due to cases of obesity, the prevalence of obesity in children reached $47.1 \%$ in 2013 (Nugrahani et al., 2016). Data from WHO in 2010 mentioned that nearly forty million children in the world under the age of five are overweight (WHO.2010). Toddlers in Asia including Indonesia have a 2.5 to $3.5 \%$ greater risk of obesity (Nugrahani et al., 2016). 
The results of the Basic Health Research (Riskesdas) in Indonesia in 2013 stated that the prevalence of obesity in children nationally experienced an increase and decrease over a period of six years from 2007 (12.2\%), 2010 (14\%), until 2013 (11.9\%) (Riskesdas, 2013). Data from the East Java Health Office stated that the prevalence of obesity among under-fives reached a high rate of $17.1 \%$, still above the prevalence rate of obesity in Indonesia. In Kediri there are 324 children under five who have fat nutritional status. The absence of programs from the health service on the handling of obesity in children, making the community also has the assumption that obesity is not a problem that must be addressed.

The causes of obesity are multifactorial, including genetic factors, socioeconomic, environmental, and behavioral conditions (Portela et al., 2015). Obesity can occur due to the interaction of genetic factors and the contribution of environmental changes (Prasetyaningrum et al., 2016). Lack of awareness of parents with overweight children, some studies show that more than $60 \%$ of parents underestimate or disregard the nutritional status of their children (Lundahl and Kidwell, 2014; Reitmeijer-Mentink et al., 2013; Tompkins et al., 2015; Howe et al., 2017).

Social factors that influence the attitudes of parents to obese children include the types of parental leadership, ethnic/ race/ ethnicity, income, education, age, and gender of children (Black et al., 2015). In a study conducted by Grazuleviciene in 2017, it was mentioned that the type of maternal care with children and smoking behavior is also associated with the incidence of obesity in children (Grazuleviciene et al., 2017). Another factor that causes obesity in children is the excessive consumption of unhealthy foods because these foods have high salt, sugar, and fat content in it (Nirvana, 2012).

Obesity in toddlers if not handled properly can continue until adulthood. Obesity has a bad impact on children as adults, not only disrupting physical health, but also psychological and social (Herawati et al., 2016). Some cardiovascular diseases can occur due to obesity are heart, stroke, diabetes, cancer, and ultimately can cause death (Wiardani et al., 2016).

One of the government's efforts to make early detection on fat nutritional status is the establishment of posyandu. One of the objectives of posyandu is to maintain and improve the health of infants, through the monitoring of nutritional status (Rahaju et al., 2008). Posyandu that currently exist still focus on malnutrition and malnutrition cases, not many posyandu that also handle obesity. Indonesian people still think that child obesity is not something that needs to be addressed.

\section{SUBJECTS AND METHOD \\ 1. Study Design \\ This was an analytics observational study with a case control design. The study was carried out in 25 posyandus located in Balowerti community health center in Kediri, East Java, from April to May 2018.}

\section{Population and Samples}

Stuydy population was all children under five in Balowerti community health center. A sample of 200 chidlren was selected by fixed disease sampling.

\section{Study Variables}

The dependent variable was children nutritional status. The independent variables were maternal nutritional status, exclusive breastfeeding, feeding pattern, food intake, and nutrition status monitoring at posyandu. 


\section{Operational Definition of Variables} Maternal nutritional status was calculated by Body Mass Index (BMI) formula, body weight $(\mathrm{kg}) /$ height $\left(\mathrm{m}^{2}\right)$. Maternal weight was measured by weight scale. Maternal height was measured by microtoise. The measurement scale was continuous.

Exclusive breastfeeding was defined as infants only received breast milk from birth to six months of ages. The data were collected by questionnaire. The measurement scale was categorical.

Feeding pattern was defined as maternal behavior in giving food to toddlers which includes food preparation, cooks, and present to child. The data were measured by questionnaire. The measurement scale was continuous.

Food intake was defined as measured from the amount of consumed food consumed consigned in the form of energy by using a 24-hour food recall. Subjects must remember what their children consumed for 24 hours from waking up to going to bed at night. The data were collected by questionnaire. The measurement scale was continuous, but for the purpose of data analysis, it was transformed into dichotomous, coded o for $<4$ times and 1 for $\geq 4$ times

Nutritional status monitoring to posyandu was defined as the regularity of children coming to posyandu for weighing for the last 6 months. The data was measured by questionnaire. The measurement scale was continuous, but for the purpose of data analysis, it was transformed into dichotomous, coded $\mathrm{o}$ for $<4$ times and 1 for $\geq 4$ times.

\section{Data Analysis}

Univariate analysis was done to see the frequency distribution and percentage characteristics of study subjects. Bivariate analysis was conducted to study the relation between performance of midwife and independent variable using chi-square test and odds ratio calculation (OR) with confidence level (CI) equal to 95\%. Multivariate analysis used a multilevel logistic regression.

\section{Research Ethics}

The research ethics include informed consent, anonymity, confidentiality and ethical clearance. The ethical clearance in this research was conducted at Dr. Moewardi hospital, Surakarta.

$\frac{\text { RESULTS }}{\text { 1. Univariate Analysis }}$

Table 1 shows that children with normal nutritional status was $143(71.5 \%)$ and overweight children was 57 (28.5\%). Mother with normal weight was 123 (61.5\%) and overweight mother was 38.5\%. Toddlers who did not receive exclusive breastfeeding were 135 (67.5\%), and those who received exclusive breastfeeding were 65 (32.5\%). Children with calorie intake $\geq$ NAR were $147(73.5 \%)$. As many as 174 (87\%) children visit posyandu to monitor their nutritional status.

\section{Table 1. Univariate Analysis}

\begin{tabular}{|c|c|c|}
\hline Variable & $\mathbf{n}$ & (\%) \\
\hline \multicolumn{3}{|c|}{ Children nutritional status } \\
\hline Normal weight & 143 & 71.5 \\
\hline Overweight & 57 & 28.5 \\
\hline \multicolumn{3}{|c|}{ Mothers nutritional status } \\
\hline Normal weight & 123 & 61.5 \\
\hline Overweight & 77 & 38.5 \\
\hline \multicolumn{3}{|c|}{ Exclusive breastfeeding } \\
\hline Not exclusive & 135 & 67.5 \\
\hline Exclusive & 65 & 32.5 \\
\hline \multicolumn{3}{|l|}{ Food pattern } \\
\hline Poor & 140 & 70 \\
\hline Good & 60 & 30 \\
\hline \multicolumn{3}{|l|}{ Calorie Intake } \\
\hline$\geq$ NAR & 147 & 73.5 \\
\hline$<\mathrm{NAR}$ & 53 & 26.5 \\
\hline \multicolumn{3}{|c|}{ Nutrition status monitoring } \\
\hline Irregular weight & 26 & 13 \\
\hline Regular weight & 174 & 87 \\
\hline
\end{tabular}


Journal of Maternal and Child Health (2018), 3(4): 261-268

https://doi.org/10.26911/thejmch.2018.03.04.03

Table 2. Bivariate analysis on the determinants of child overweigth

\begin{tabular}{|c|c|c|c|c|c|c|c|c|c|}
\hline \multirow{2}{*}{ Independent Variables } & \multicolumn{2}{|c|}{ Normal } & \multicolumn{2}{|c|}{ Fat } & \multicolumn{2}{|c|}{ Total } & \multirow{2}{*}{ OR } & \multirow{2}{*}{$95 \% \mathrm{CI}$} & \multirow[b]{2}{*}{$\mathbf{p}$} \\
\hline & $\mathbf{n}$ & $\%$ & $\mathbf{N}$ & $\%$ & $\mathbf{n}=\mathbf{2 0 0}$ & $\%$ & & & \\
\hline \multicolumn{10}{|l|}{ Maternal BMI } \\
\hline Normal & 95 & 23 & 28 & 77 & 123 & 100 & \multirow[t]{4}{*}{2.05} & 1.98 to & \multirow[t]{3}{*}{0.023} \\
\hline Overweight & 48 & 62.3 & 29 & 37.7 & 77 & 100 & & 3.82 & \\
\hline \multirow{2}{*}{\multicolumn{9}{|c|}{$\begin{array}{l}\text { Exclusive Breastfeeding } \\
\text { Not Exclusive }\end{array}$}} & \\
\hline & & & & & & & & & \\
\hline Breastfeeding & 90 & 66.7 & 45 & $33 \cdot 3$ & 135 & 100 & \multirow[t]{2}{*}{2.208} & 1.073 to & \multirow[t]{2}{*}{0.029} \\
\hline $\begin{array}{l}\text { Exclusive Breastfeeding } \\
\text { Feeding Pattern }\end{array}$ & 53 & 81.5 & 12 & 18.5 & 65 & 100 & & 4.55 & \\
\hline Poor & 93 & 66.4 & 47 & 33.6 & 140 & 100 & \multirow[t]{3}{*}{2.52} & 1.17 to & \multirow[t]{3}{*}{0.015} \\
\hline Good & 50 & 83.3 & 10 & 16.7 & 60 & 100 & & 5.42 & \\
\hline \multicolumn{8}{|l|}{ Calorie Intake } & & \\
\hline According to NAR & 121 & 82.3 & 26 & 17.6 & 147 & 100 & \multirow[t]{4}{*}{6.55} & 3.28 to & \multirow[t]{2}{*}{$<0.001$} \\
\hline Exceeding the NAR & 22 & 41.5 & 31 & 58.5 & 53 & 100 & & 13.09 & \\
\hline \multirow{2}{*}{\multicolumn{9}{|c|}{$\begin{array}{l}\text { Nutritional Status } \\
\text { Monitoring }\end{array}$}} & \\
\hline Monitoring & & & & & & & & & \\
\hline Irregular Weight & 1 & 4 & 25 & 96 & 26 & 100 & \multirow[t]{2}{*}{0.35} & 0.17 to & \multirow[t]{2}{*}{0.002} \\
\hline Regular Weight & 142 & 81.6 & 32 & 18.4 & 174 & 100 & & 069 & \\
\hline
\end{tabular}

Table 3. The result of multilevel logistic regression

\begin{tabular}{lcccc}
\hline \multicolumn{1}{c}{ Variable } & Coefficient & \multicolumn{2}{c}{$\mathbf{9 5 \%}$ CI } & \multirow{2}{*}{ p } \\
\cline { 3 - 4 } & (b) & Lower Limit & Upper Limit & \\
\hline Fixed Effect & & & & \\
Maternal Nutritional Status & 0.72 & -0.98 & 1.54 & 0.085 \\
Exclusive Breastfeeding & -0.97 & -1.98 & 0.02 & 0.057 \\
Feeding Pattern & 1.11 & -2.15 & -0.08 & 0.034 \\
Food Intake & & 0.59 & 2.31 & 0.001 \\
Random Effect & -4.34 & -6.42 & & \\
Nutritional Status Monitoring & 2.66 & 0.53 & 4.21 & $<0.001$ \\
Var (Constants) & & & & 0.014 \\
Observation Score= 200 & & & & \\
ICC =.98\% & & & & \\
Likelihood Ratio Test $\mathrm{p}=-75.06$ & & &
\end{tabular}

\section{The results of bivariate analysis}

The bivariate analysis looked at the relationship between independent variables (maternal nutritional status, exclusive breastfeeding, feeding pattern, food intake, and nutritional status monitoring at health center) and dependent variable (overweight). The result of bivariate analysis can be seen in table 2 .

\section{Multilevel Analysis}

Table 3 shows that maternal nutritional status was associated with overweight in children under five. Overweight children increased the risk of overweight among children $(b=0.72 ; 95 \% \mathrm{CI}=-0.98$ to 1.54 ; $\mathrm{p}=0.085$ ).
There was a negative effect between exclusive breastfeeding and overweight in children under five. Exclusive breastfeeding reduced the risk of overweight in children $(b=-0.97 ; 95 \% \mathrm{CI}=-1.98$ to $0.02 ; \mathrm{p}=$ 0.057).

There was a negative effect between feeding pattern and child overweight. Good feeding pattern reduced the risk of overweight among children $(b=-1.11 ; 95 \% \mathrm{CI}=$ 2.15 to $-0.08 ; \mathrm{p}=0.034)$.

There was a positive effect between food intake and overweight in children. Higher food intake ( $\geq$ NAR) increased the risk of overweight in children $(b=1.45 ; 95 \%$ $\mathrm{CI}=0.59$ to $2.31 ; \mathrm{p}=0.001$ ). 
There was a negative effect of nutritional status monitoring at posyandu and child overweight. Regular nutritional status monitoring at posyandu reduced the risk of child overweight $(b=-4.34 ; 95 \% \mathrm{CI}=-6.42$ to $-2.21 ; \mathrm{p}<0.001$ ).

In table 3 , the score of $\mathrm{ICC}=0.98 \%$. The indicator showed that the health center in each strata has less contextual effect on the status of obese toddlers in health center. Lack of cadres and health personnel activeness in handling obese toddlers lead to lack of contextual effect of health center on obese toddlers at the community level. Most of nutrition program of toddlers at health center still focused on malnourished and stunting toddlers only. There was still no program from health services, community health center, and health center regarding the handling of obese toddlers.

However, from the results of individual levels, it can be concluded that the multivariate effect explained about the influence of more than the independent variables namely maternal nutritional status, exclusive breastfeeding, feeding pattern, food intake, and monitoring of nutritional status in posyandu.

\section{DISCUSSION}

\section{The effect of maternal nutritional} status on child overweight

There was a significant effect between maternal nutritional status and child overweight. Overweight mother increased the risk of overweight in their children.

The result of this study was in line with a study by James et al. (2013) and Portela et al. (2015), which stated that obesity in mothers has a strong relationship with the obesity in their children.

Factors of parental nutritional status could affect the obesity in toddlers because the behavior of parents in eating foods and physical activity could affect the children to support the obesity and obesity can also be derived genetically (James et al., 2013). Obese mothers did not directly make their children fat, however, this relationship can be caused by some unhealthy parental behavior that could be imitated by the children and even formed behavioral habits for children that lead to the occurrence of obesity.

\section{The effect of exclusive breastfeed- ing on overweight}

There was a statistically significant effect between exclusive breastfeeding and child overweight. Exclusive breastfeeding reduced the risk of child overweight Park et al. (2018), Marseglia et al. (2015), Yan et al. (2014), Nugrahani et al. (2016), Saputri, (2013).

Children who did not receive exclusive breastfeeding increased the risk overweight 4.2 (Saputri, 2013). Longer breastfeeding reduced the incidence of obesity in children (Yan et al., 2014). Giving formula milk and weaning food at an early age for infant can lead to abnormal fat deposit and increased the risk of obesity in children under five (Park and Lee, 2018).

The content of nutrients contained in breast milk was a component that has been complete and appropriate for the baby. If formula milk or other food was given to the children, it could disturb the balance of absorption of existing nutrients that can lead to obesity in children.

\section{The effect of feeding pattern on child overweight}

There was a negative effect between feeding pattern and overweight in children. Good feeding pattern reduced the risk of child overweight. This findings is in line with (Purnama et al., 2015) (Herawati et al., 2016) (Demir et al., 2017).

Parental behavior can also affect the eating behavior of the children, which in this case was the parental behavior in 
feeding their children (Herawati et al., 2016). If the parents did not control the food intake of their children, it would increase the risk of obesity in children (Purnama et al., 2015).

Children were very easy to imitate what was done by their parents, if the parents often consume foods, especially high-calorie and high sugar type of foods, then this would also be imitated by the children. The type of food consumed or available at home would also depend on parental preferences. In addition, children were still not able to independently determine what they eat, so it was the parents' duty to prepare the food for children. The behavior of feeding patterns for children could affect the incidence of obesity.

\section{The effect of food intake on child overweight}

There was a positive effect between food intake and child overweight. Higher food intake increased the risk of overweight among children under five. This finding is in line with Huang et al. (2015), Mandal et al. (2014), and Setiyaningsih et al. (2015).

Components of nutrients such as calcium and fiber was very influential to suppress the occurrence of obesity in children, while vitamin $B$, high-sugar foods, and carbohydrates can caused obesity (Huang et al., 2015). Children who consumed unhealthy foods $\geq 32$ times/week tend to have higher risk by 4.26 times for obesity than toddlers who consume unhealthy foods $<32$ times/week (Setiyaningsih et al., 2015).

Children were generally very difficult to eat vegetables and fruit, they prefer fried food, high sugar, and high salt. This highcalorie food intake without parental control can certainly cause obesity in children. Currently, any kind of variation of snacks or fast food was more diverse and also made the toddlers to eat high-calorie foods.

\section{The effect of nutritional status monitoring on overweight}

There was a negative effect of nutritional status monitoring in posyandu on overweight among children under five. Nutritional status monitoring in posyandu reduced reduced the risk of overweight.

Posyandu was the first place for children to monitor their nutritional status. If the health center was poorly utilized by parents, it can be ascertained that children with fat nutritional status would not get any intervention.

There were still many assumptions in the community that obese toddlers were adorable and healthy, so that many parents did not consider that fat was an issue of abnormal nutritional status. Posyandu was supposed to monitor child nutritional status.

\section{REFERENCE}

Badan Penelitian dan Pengembangan Kesehatan Kementrian Kesehatan RI (2014). Laporan Hasil Riset Kesehatan Dasar 2013. Jakarta: Departemen Kesehatan Republik Indonesia.

Black J, Black JA, Park M, Gregson J, Falconer CI, White B, Kessel AS, Kinra S (2015). Child obesity cut-offs as derived from parental perceptions. $\mathrm{Br} \mathrm{J}$ Gen Pract. 65 (633): e234-e239. doi: 10.3399/bjgp15X684385.

Demir D, Bektas M (2017). Eating Behaviors The effect of children eating behaviors and parental feeding style on childhood obesity. Eating Behavior. Elsevier Ltd, 26. 137-142. doi: 10.1016/j.eatbeh.2017.03.004.

Grazuleviciene R, et al. (2017). Psychosocial stress and obesity among children residing in Kaunas City. Environmental Research. Elsevier Inc. 157: 37-43. doi: 10.1016/j.envres.2017.05.002.

Herawati HD, Gamayanti IL, Tsani AFA, 
(2016). Perilaku makan berlebih dan hubungannya dengan kegemukan pada anak prasekolah. (1).

Howe CJ, Alexander G, Stevenson J (2017). Journal of Pediatric Nursing Parents Underestimations of Child Weight: Implications for Obesity Prevention. Journal of Pediatric Nursing. Elsevier Inc. doi: 10.1016/j.pedn.2017.06.005.

Huang J, Qi S (2015). Childhood obesity and food intake. World $\mathrm{J}$ Pediatr. 11(2): 101-102. doi: 10.1007/s12519015-0018-2.

James KS, Matsangas P, Connelly CD (2013). Childhood Obesity Risk in Overweight Mothers: Support for Screening 5(6): 375-382. doi: 10.1177/1941406413501865.

Luh N, Purnama A (2015). Perilaku orang tua dalam pemberian makan dan status gizi anak usia 2-5 tahun. Jurnal Gizi Klinik Indonesia, 11(3): 97-104.

Lundahl A, Kidwell KM, Nelson TD (2014). Parental Underestimates of Child Weight: A meta-analysis. Pediatrics, 133(3): 689-703.

Mandal B, Powell LM (2014). Economics and Human Biology Child care choices, food intake, and children's obesity status in the United States. Economics and Human Biology. Elsevier B.V. 14: 50-61. doi: 10.1016/j.ehb.2014.04.001.

Marseglia L, et al. (2015). Obesity and breastfeeding: The strength of association. Women and Birth. Australian College of Midwives, 28(2): 81-86. doi: 10.1016/j.wombi.2014.12.007.

Nirwana A (2012). Obesitas Anak dan Pencegahannya. Yogyakarta: Nuha Medika.

Nugrahani ER, Sulistyorini L, Rahmawati I (2016). Perbedaan Kejadian Gizi Lebih pada Balita Usia 1-2 tahun dengan Riwayat Pemberian Asi Eks- klusif dan Bukan Asi Eksklusif di Desa Tanggul Kulon Wilayah Kerja Puskesmas Tanggul Kecamatan Tanggul Kabupaten Jember (The Difference of the Overweight Incidence, 4(2).

Park S, Lee H (2018). Exclusive breastfeeding and partial breastfeeding reduce the risk of overweight in childhood: A nationwide longitudinal study in Korea. Obesity Research \& Clinical Practice. Asia Oceania Assoc. for the Study of Obesity, 12(2): 222-228. doi: 10.1016/j.orcp.2018.01.001.

Portela DS, et al. (2015). Maternal obesity, environmental factors, cesarean delivery and breastfeeding as determinants of overweight and obesity in children: results from a cohort. 1-10. doi: 10.1186/s12884-015-0518-z.

Prasetyaningrum, Nyoman KIMAG (2016). Status ketersediaan makanan dan status gizi ibu sebagai faktor risiko kegemukan pada anak prasekolah. 13(2): 75-81.

Rahaju B, Utami DW, Dewi V (2008). Buku Pegangan Kader Posyandu. Dinas Kesehatan Propinsi Jawa Timur.

Reitmeijer-Mentink M, Paulis WD, Middelkoop M, Bindels PJ, Wouden JC (2013). Difference between Parental Perceptions and Actual Weight Status of Children: A Systemic Review. Maternal and Child Nutrition. 9(1): 322.

Setiyaningsih YE, Nurwanti E, Pratiwi AM (2015). Konsumsi unhealthy food sebagai faktor risiko obesitas pada balita di Puskesmas Jetis, Kota Yogyakarta. (1).

Tomkins CI, Seablom M, Brock DW (2015). Parental Perception of Childs Body Weight: A Systematic Review. Journal of Child and Family Studies, 24(5): 1384-1391.

Wiardani NK (2016). Penatalaksanaan Diet 
Journal of Maternal and Child Health (2018), 3(4): 261-268

https://doi.org/10.26911/thejmch.2018.03.04.03

Obesitas: 280-307. In Hardiansyah \& I Dewa Nyoman Supariasa (edt), Ilmu Gizi: Teori dan Aplikasi. Jakarta: EGC.

World Health Organization (2010). Childhood overweight and obesity on the rise. Geneva.
Yan J, Liu L, Zhu Y, Huang G, Wang PP (2014). The association between breastfeeding and childhood obesity: a meta-analysis. BMC Public Health. 14:1267 doi: 10.1186/1471-2458-141267. 